\title{
Production of Poly- $\alpha$-hydroxybutyrate (PHB) from Sago Starch by The Native Isolate Bacillus megaterium PSA10
}

\author{
Nur Arfa Yanti ${ }^{1,2^{*}}$, Langkah Sembiring ${ }^{2}$, and Sebastian Margino ${ }^{3}$
}

1.Study Program of Biology, FKIP, Haluoleo University, Kendari, Indonesia

2.Laboratory of Microbiology, Faculty of Biology Gadjah Mada University, Yogyakarta, Indonesia

3.Laboratory of Agriculture Microbiology, Faculty of Agriculture, Gadjah Mada University,

Yogyakarta, Indonesia

\begin{abstract}
A new bacterial strain that produces amylase and poly- $\alpha$-hidroxybutyrate (PHB) using sago starch as carbon source was characterized and identified to be member of the Bacillus megaterium group based on phenotypic characteristics and 16S rDNA gene sequences. Amylase activity was determined spectrophotometrically on the basis of substrate concentration reduction. PHB production was quantified with UV spectrophotometer. The polymer produced by B. megaterium PSA10 was identified by Fourier Transform Infrared spectroscopy (FTIR). The result of the study showed that the amylase specific activity B. megaterium PSA10 was 593,61 DUN/mg protein and PHB production from sago starch was $52,28 \%$ of cell dry weight (CDW). FTIR analysis of the polymer indicated that the strain B.megaterium PSA10 was a potent PHB producer.
\end{abstract}

Keywords : Amylase, Poly- $\alpha$-hydroxybutyrate (PHB), Bacillus megaterium, 16S rDNA

\section{Introduction}

Poly- $\alpha$-hydroxybutyrate $(\mathrm{PHB})$ is a biodegradable polyesters accumulated as carbon and energy storage compounds by a variety of bacterial species under nutrient (Nitrogen or Phosphorous) limiting conditions with excess carbon. PHB is biodegradable, water insoluble, non-toxic, bio-compatible and thermoplastic and therefore it is suitable for application in the packaging industry and an appropriate substitute for hydrocarbon based plastic (Anderson and Dawes, 1990). Economic considerations of production cost suggest that the carbon source has a high impact on the production cost of PHB, affecting its commercialization potential (Byrom, 1987). There has

\footnotetext{
*) Correspondence address : Nur Arfa Yanti, Laboratory of Microbiology, Faculty of Biology, Gadjah Mada University,Yogyakarta, Indonesia E-mail : arfayanti73@yahoo.com
}

been a considerable interest in using cheap substrates as an alternative to substitute glucose in PHB production. In order to lower down the cost production, it is essential to identify the microorganisms that utilize cheaper carbon sources efficiently to produce PHB.

Sago starch is a renewable carbon source which is potential as carbon source for PHB production due to its high carbon content whereas nitrogen and phosphorous content are low (Singhal et al., 2008). Utilization of sago starch in these processes needs enzymatic hydrolysis for starch degradation. This suggests that there is a need for exploitation and identification of a bacterial culture for the co-production of starch hydrolyzing enzyme as well as PHB.

In this study, direct production of PHB from sago starch was carried out using strain PSA10. Characterization and identification of the native strain PSA10 was done using phenotypic and molecular techniques. 
Its ability to produce amylase, as a basis for starch hydrolysis and identification of the polymer produced by strain PSA10 were determined.

\section{Materials and Methods \\ Bacterial strain and media}

Strain PSA10 was isolated from sago wet flour sample which obtained from sago starch processing area in Kendari Sulawesi Tenggara. Bacillus megaterium FNCC 0083 and Bacillus amyloliquefaciens FNCC 0079 were used as reference strains. All strains were maintained in starch nutrient agar slants.

Medium for production of PHB was mineral salt medium (Ramsay et al., 1990) composed of $\left(\mathrm{l}^{-1}\right): 1.0 \mathrm{~g}\left(\mathrm{NH}_{4}\right)_{2} \mathrm{SO}_{4}, 6.7 \mathrm{~g}$ $\mathrm{Na}_{2} \mathrm{HPO}_{4} .7 \mathrm{H}_{2} \mathrm{O}, 1.0 \mathrm{~g} \mathrm{KH}_{2} \mathrm{PO}_{4}, 0.2 \mathrm{~g}$ $\mathrm{MgSO}_{4} 7 \mathrm{H}_{2} \mathrm{O}, 60 \mathrm{mg}$ Ferrous Amonium Citrate, $10 \mathrm{mg} \mathrm{CaCl} \cdot 2 \mathrm{H}_{2} \mathrm{O}, 1 \mathrm{ml}$ trace element and $10 \mathrm{~g}$ sago starch as carbon source. The growth medium used for amylase production composed of $\left(\mathrm{l}^{-1}\right): 10 \mathrm{~g}$ soluble starch, 2 $\mathrm{g}\left(\mathrm{NH}_{4}\right)_{2} \mathrm{SO}_{4}, 1 \mathrm{~g} \mathrm{~K}_{2} \mathrm{HPO}_{4} 1 \mathrm{~g} \mathrm{MgSO}_{4} .7 \mathrm{H}_{2} \mathrm{O}$, $1 \mathrm{~g} \mathrm{NaCl}$ and $3 \mathrm{~g} \mathrm{CaCO}_{3}$. The $\mathrm{pH}$ of the media was adjusted to $\mathrm{pH} 7,0$ with $1 \mathrm{~N}$ $\mathrm{NaOH}$ and was autoclaved at $121^{\circ} \mathrm{C}$ for 15 $\min$.

\section{Amylase activity assay}

The ability of the bacteria to hydrolyze starch was initially tested on starch agar containing $0,3 \%(\mathrm{w} / \mathrm{v})$ of starch. The strain of $B$. megaterium FNCC 0083 and $B$. amyloliquefaciens FNCC $0079^{\mathrm{T}}$ were used as reference strains. The clear zone around the colony was measured upon pouring iodine. The assay for measuring the activity of the amylase enzyme was determined by using the procedure described by Espino and Tambalo (1997). One unit of enzyme activity (DUN) is defined as amount of enzyme that causes $10 \%$ reduction of blue color intensity of the starch-iodine complex at the specified condition. The protein concentra- tion was determined by the Bradford method, with bovine serum albumin as standard.

\section{Production and determination of $\mathrm{PHB}$}

The culture was grown in mineral salt medium supplemented with sago starch as carbon source for PHB production. $50 \mathrm{ml}$ medium was distributed in the $250 \mathrm{ml}$ erlenmeyer flasks and then were inoculated with $5 \%(\mathrm{v} / \mathrm{v})$ inoculum of $24 \mathrm{~h}$ grown culture and incubated at $150 \mathrm{rpm}$ for $72 \mathrm{~h}$ at $30^{\circ} \mathrm{C}$. The pellet was collected by centrifugation at $3000 \mathrm{rpm}$ for $20 \mathrm{~min}$ and pellet was digested with $30 \%$ sodium hypochlorite solution at $30^{\circ} \mathrm{C}$ for overnight. The residue was collected by centrifugation at $3000 \mathrm{rpm}$ for $20 \mathrm{~min}$ and a series of washing steps using water, acetone and finally diethyl ether was performed (Senior et al., 1972). The polymer was added with concentrated $\mathrm{H}_{2} \mathrm{SO}_{4}$ and heated for $10 \mathrm{~min}$ at $100^{\circ} \mathrm{C}$ in a water bath. The resultant crotonic acid was measured spectrophotometrically (Shimadzu UV-6A) at $235 \mathrm{~nm}$ against $\mathrm{H}_{2} \mathrm{SO}_{4}$ as blank.

\section{Identification of the produced polymer}

The identification of the biopolymer was carried out using Fourier transform-infrared spectroscopy (FT-IR). The polymer was obtained by dissolving it in chloroform. Precipitate was separated by centrifugation and then poured on petri dish to evaporate the chloroform, resulting a thin film of solid. This film was used for FTIR analysis (Misra et al., 2000). FTIR spectrum was produced by using Prestige-21 Shimadzu fourier transform-infrared spectrometer. PHB from Sigma was used as a standard.

\section{Identification of strain PSA10}

The strain PSA10 was identified based on phenotypic and genotypic characterization. Phenotypic characterization was performed by examining morphological prop- 
erties (cell shape, cell size, gram reaction, motility, and spore forming), biochemical test (catalase, nitrate reduction, hydrolysis of casein, gelatin, tween 80, starch, Methyl Red and Voges-Proskauer test, indole test, citrate utilization and sugar utilization) and physiological test (influence of $\mathrm{pH}$, salt and temperature on growth).

Identification of PSA10 based on genotypic characterization was conducted by $16 S$ rDNA sequence comparison. Genomic DNA from PSA10 strain was obtained as described by Song et al. (2004). Amplification of $16 \mathrm{~S}$ rDNA by PCR was done using universal bacterial primer 27f (5'AGAGTTTAGTCCTGGCTCAG-3') and 1529R (5'-CAIAAAGGAGGTGATCC-3'). PCR product was checked in $2 \%(\mathrm{w} / \mathrm{v})$ agarose gel electrophoresis. The PCR product was purified using microclean kit (Microzone Ltd.). Purified 16S rDNA was sequenced using ABI PRISM 310 big dye terminator cycle sequence reading reaction kit, according to the protocol of the manufacturer (Applied Biosystems). Base sequences were determined in an Applied Biosystems model 310 genetic analyzer.

The 16S rDNA sequence of PSA10 strain was aligned with representative bacteria 16S rDNA sequences retrieved from in the NCBI nucleotide sequence database (http://www.ncbi.nlm.nih.gov) and was edited manually. Pairwise evolutionary similarities and distances were computed by using the DNADIST program in the phylogeny inference package (PHYLIP) versi on 3,5 (Felsenstein, 1995). The phylogenetic tree was constructed by using the Neighbourjoining algorithm (Saitou and Nei, 1987). The root position of the unrooted tree was estimated by using Streptomyces albus DSM $40313^{\mathrm{T}}$ as the outgroup strain.

\section{Results and Discussion}

Strain PSA10 was a gram positive and rod shape bacteria (Figure 1A) that had abil- ity to produce amylase enzyme and to accumulate of PHB granule inside cell (Figure $1 b)$. The ability of strain PSA10 to show clear zone on starch agar plates (Figure 1c), indicated that strain PSA10 was able to produce amylase enzyme. Amylase activity, protein content and amylase specific activity of strain PSA10 was achieved 42,74 DUN/ml, 0,072 mg/ml and 594,61 DUN/ mg protein, respectively. This result formed the basis of using sago starch as carbon source which can also be considered as a factor to lower cost of PHB production.

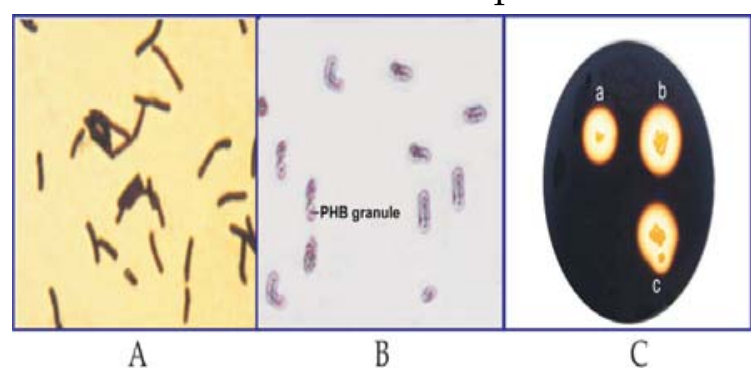

Figure 1. Characteristic features of strain PSA10. A morphology cell, B cell with PHB granule after Sudan black staining of the strain PSA10, C comparative starch hydrolysis test: (a) PSA10, (b) B. amyloliquefaciens FNCC 0079, (c) B. megaterium FNCC 0083

Strain PSA10 was found to produce $52,28 \%$ PHB of cell dry weight (CDW) using sago starch as carbon source, after $72 \mathrm{~h}$ of fermentation. This result suggested efficient utilization of sago starch for the PHB production. The ability of strain PSA10 to produce PHB from sago starch directly, can provide a better alternative than the two steps of enzymatic hydrolysis of starch followed by PHB production. Previously, the strain Azotobacter chroococcum 23, Haloferax mediterrania and Bacillus cereus CFR06 were employed to produce PHB in soluble starch medium directly (Kim and Chang, 1998; Halami, 2008).

In order to confirm the identify of PHB, then the polymer was isolated and characterized using FTIR. The FTIR spectroscopic analysis of the isolated polymer (Figure 2), revealed mainly two intense absorption 
bands at $1728,22 \mathrm{~cm}-1$, corresponding to the ester carbonyl group $(\mathrm{C}=\mathrm{O})$ and at 1280,73 corresponding to $\mathrm{C}-\mathrm{O}$ stretching group. Both of bands are characteristic of PHB (Misra et al,. 2000; Vallapil et al., 2007a). The absorption bands at 1724,03 and 1280,73 cm-1 were found in polymer produced by PHB producer such as Alcaligenes eutrophus MTCC 1954, Pseudomonas citronellolis 1191 and Methylobacterium extorquens MTCC 298 whereas these bands were absent in non producer PHB, Escherichia coli (Misra et al., 2000). Therefore from this observation, it can be concluded that PSA10 was able to produce PHB.

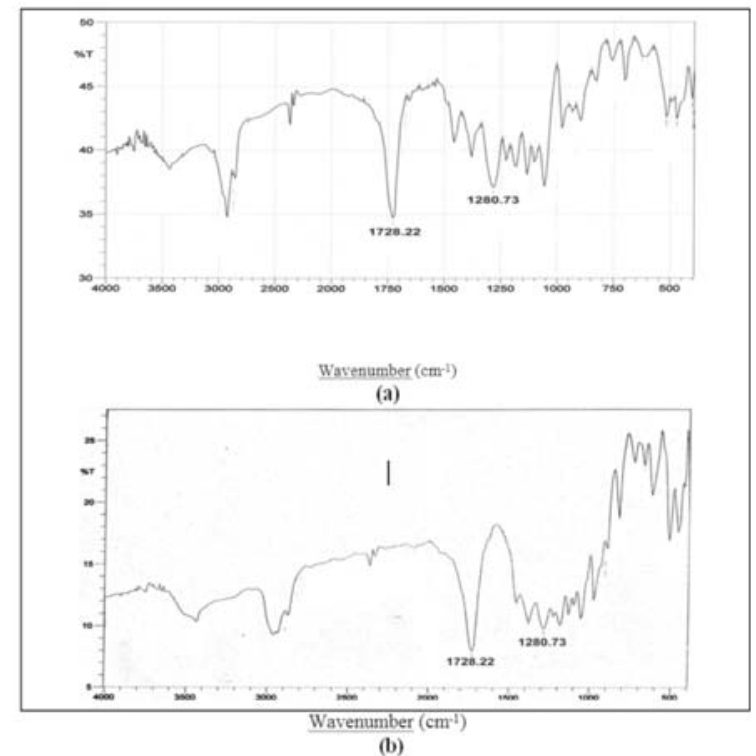

Figure 2. Fourier transform-infrared absorption spectra of (a) polymer from strain PSA10 grown in sago starch media and (b) standard PHB from SigmaAldrich

Identification of strain PSA10 was done based on phenotypic and genotypic characterization. The phenotypic properties of strain PSA10 is summarized in Table 1 . Phenotypic characteristics revealed that the PSA10 strain was gram positive, rod shape, motile, catalase positive and endospora forming. These characters were matched with key characters for genus Bacillus (Holt et al., 1994) so that PSA10 was identified as a member of genus Bacillus.

Table 1. Phenotypic characteristics of strain PSA10 and genus Bacillus

\begin{tabular}{|c|c|c|}
\hline Characteristics & PSA10 & Bacillus \\
\hline \multicolumn{3}{|l|}{ Morphology } \\
\hline Cell shape & Rod & Rod \\
\hline Cell size $(\mu \mathrm{m})$ & $1,5 \times 5-10$ & $\begin{array}{c}0,5 \times 1,2 \text { (small) } \\
2,5-10 \text { (large) }\end{array}$ \\
\hline Motility & + & + \\
\hline Endospora & + & + \\
\hline Gram staining & Positive & Positive \\
\hline \multicolumn{3}{|l|}{ Cultural characteristic } \\
\hline Colony shape & Circular & Variable \\
\hline Growth on nutrient broth $\mathrm{pH} 5,0-7,0$ & + & + \\
\hline Growth in $\mathrm{NaCl} 2,0-5,0 \%$ & + & + \\
\hline Growth at 5,15 and $60^{\circ} \mathrm{C}$ & - & - \\
\hline \multicolumn{3}{|l|}{ Biochemical properties } \\
\hline Catalase & + & + \\
\hline Nitrate reduction & - & $+/-$ \\
\hline Urease production & - & $+/-$ \\
\hline Methyl red & + & $+/-$ \\
\hline Voges-proskauer & - & $+/-$ \\
\hline Casein hydrolysis & + & + \\
\hline Gelatin hydrolysis & - & - \\
\hline Tween 80 hydrolysis & + & + \\
\hline Starch hydrolysis & + & $+/-$ \\
\hline PHB accumulation & + & $+/-$ \\
\hline Acid production from : & & \\
\hline Glucose, sucrose, maltose & + & + \\
\hline $\begin{array}{l}\text { Rhamnose, dextrose, xylose, } \\
\text { mannitol, galactose, L-Arabinose }\end{array}$ & + & $+/-$ \\
\hline Gas production from glucose & & $+/-$ \\
\hline
\end{tabular}

Based on phenotypic characteristics, it can be obtained several information for further application of strain PSA10. The ability of PSA10 to hydrolyze casein indicated that the native strain PSA10 is a potential producer of proteolytic enzymes. The strain showed luxurious growth at $50^{\circ} \mathrm{C}$ and in $5 \%(\mathrm{w} / \mathrm{v})$ salt concentration (Table 1$)$ suggesting that the strain is tolerant to relatively high temperature and salt concentration. The ability of PSA10 to utilize various sugars was determined by carbohydrate fermentation test (Table 1) provided the basis for exploration the carbon source for the production of PHB.

Genotypic characterization study was carried out to identify strain PSA10 after studying phenotypic characteristics. This study includes $16 \mathrm{~S}$ rDNA analysis, which is considered as a most standard and reliable method for identification of an unknown microorganism. Comparative 16S rDNA sequence analyses and the estimation of phylogenetic relationships demonstrated that the closest relative of strain PSA10 was 
Bacillus megaterium IMER-B2-34 (99,33\% similarity) (Figure 3). The $16 \mathrm{~S}$ rDNA sequence similarity with the type strain of the species $B$. megaterium was $98,47 \%$, clearly indicating that PSA10 belong to this species (Figure 3). Therefore a new strain, name ' $B$. megaterium PSA10' was assigned to this efficient producer of PHB using sago starch as carbon source.

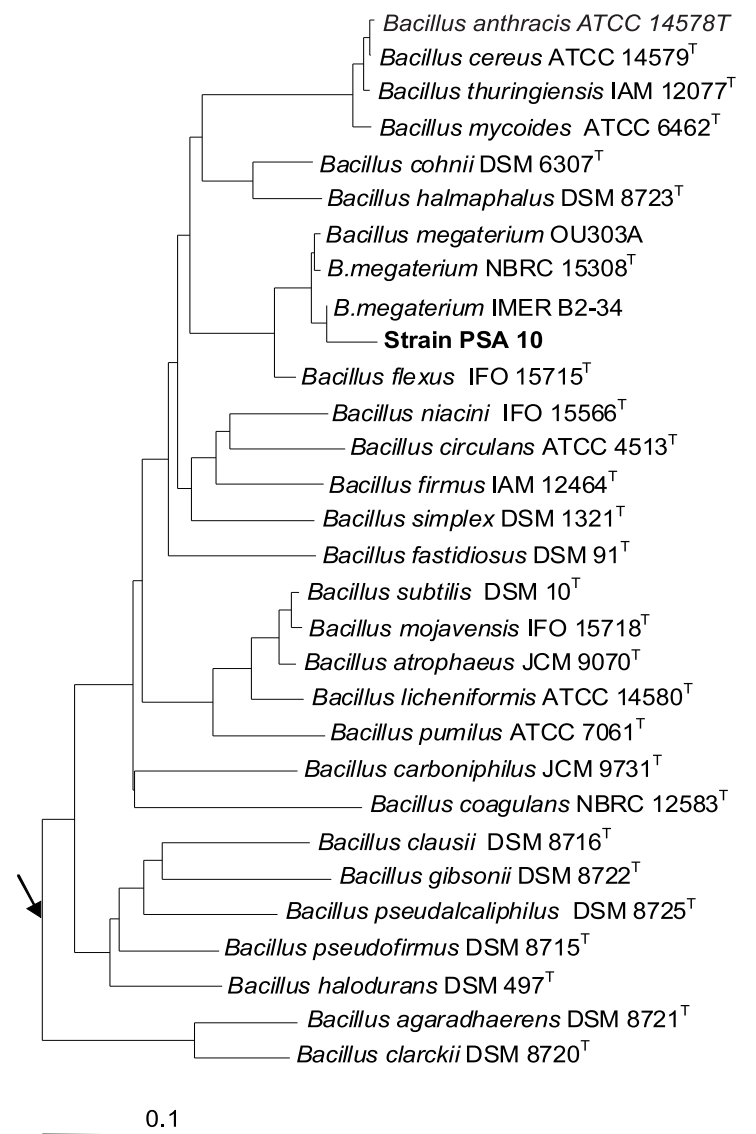

Figure 3. Phylogenetic tree showing relationships between strain PSA10 and representatives of the genus Bacillus based on 165 rDNA sequences. The arrow indicates the estimated root position of the tree. The scale bar indicates 10 nucleotide substitution per 100 nucleotides in 16S rRNA gene sequences

A number of strains belong to genus Bacillus have been reported as PHB producers, with the ability to produce PHB 9-48\% of CDW (Aslim et al., 2002; Yilmas et al., 2005; Valappil et al., 2007a; Halami, 2008).
In comparison with other related literatures, our results showed that a higher PHB production. Therefore, $B$. megaterium PSA10 was regarded to be a potential PHB producer.

According to Valappil et al. (2007b), utilization of Gram-positive bacteria as a PHB producer for medical applications has an advantage in comparison with Gramnegative bacteria. Gram-negative bacteria have lipopolysaccharides (LPS) which can cause immunogenic reaction. Furthermore, Gram-positive bacteria lack LPS (Valappil et al., 2007b), hence B. megaterium PSA10 is potentially better source of $\mathrm{PHB}$, especially for biomedical applications.

\section{References}

Anderson, A.J. and Dawes, E.A. 1990. Occurrence, Metabolism, Metabolic Role and Industrial Uses of Bacterial Polyhydroxyalkanoate. Microbiol. Revi. 54 (4), 450-472.

Aslim, B., Yuksekdag, Z.N. and Beyatli, Y. 2002. Determination of PHB Growth Quantities of Certain Bacillus Species Isolated from Soil. Turkish Elect. Jour. Biotechn. 24-30.

Byrom, D. 1987. Polymer Synthesis by Microorganisms : Technology and Economics. Tibtech.5,246 - 250.

Espino, T.M. and Tambalo, R.D. 1997. Isolation, Screening and Characterization of High Yielding $\alpha-$ Amylase Producing Bacteria. Ann. Rep. IC Biotech. 20, 744-754.

Felsenstein, J. 1995. PHYLIP (Phylogeny Inference Package) version 3,57c. Seattle. University of Washington.

Halami, P.M. 2008. Production of polyhydroxyalkanoate from starch by the native isolate Bacillus cereus CFR06. Wor. Jour. Microbiol. and Biotech. 24, 805-812. 
Holt, J.G., Krieg, N.R., Sneath, P.H.A., Stanley, J.T. and Williams, S.T. 1994. Bergey's Manual of Determinative Bacteriology. $9^{\text {th }}$ ed. Lipincot, Williams and Wilkins, Baltimore.

Kim, B.S and Chang, N.H. 1998. Production of Poly (3-hydroxybutyrate) from Starch by Azotobacter chroococcum. Biotech. Lett. 20 (2), 109-112.

Misra, A.K., Thakur, M.S., Srinivas, P. and Karanth, N.G. 2000. Screening of poly$\alpha$-hydroxybutyrate producing microorganisms using Fourier transform infrared spectroscopy. Biotech. Lett. 22,1217-1219

Ramsay, B.A., Lomaliza, K., Chavarie, C., Dube, B., Bataille, P. and Ramsay, J.A. 1990. Production of Poly-( $($ $\mathrm{H}$ y d r o x y b u t y r i $-\mathrm{Co-}-\mathrm{B}-$ Hydroxyvaleric) Acids. App. Envir. Microbiol. 56 (7),2093-2098.

Saitou, N. and Nei, M. 1987. The Neighbour-joining Method : A New Method for Reconstructing Phylogenetic Trees, Mol. Biol. and Evol. 4,406-426.

Senior, P.J., Beech, G.A., Ritchie, G.A.F. \& Dawes, E.A. 1972. The Role of Oxygen Limitation in the Formation of Polyb-hydroxybutyrate during Batch and Continuous Culture of Azotobacter beijerinckii. Biochem.Jour.128, 11931201.

Singhal, R.S., Kennedy, J.F., Gopalakrishnan, S. M., Kaczmarek, A., Knill, C. J. and Akmar, P.F. 2008. Industrial production, processing, and utilization of sago palm-derived products. Carbo. Poly. 72,1-20
Song, J., S. Lee, J. Kang, H. Baek and J. Suh, 2004, Phylogenetic analysis of Streptomyces spp. Isolated from potato scab lesions in Korea on the basis of $16 S$ rRNA gene and 16S-23S rDNA internally transcribed spacer Sequences. Intl.Jour. Syst. Evol. Microbiol. 54, 203-209

Valappil, S.P., Misra, S.K., Boccaccini, A.R., Keshavars, P., Bucke, C. and Roy, I. 2007a. Large-scale Production and Efficient Recovery of PHB with Desirable Material Properties, from The Newly Characterised Bacillus cerus SPV. Jour. Biotech., 127,452-460

Valappil, S.P. Boccacini, A.R. Bucke E.A. and Roy, E.I. 2007b. Polyhydroxyalkanoates in Grampositive bcteria : insights from the Genera Bacillus and Streptomyces. Antonie van leeuwenhoek. 91,1-17

Yilmaz, M., Soran, H. \& Beyatli, Y. 2005. Determination of Poly- $\alpha$ hydroxybutyrate (PHB) production by some Bacillus spp. World Jour. Microbiol. Biotech. 21.565-566 